\title{
解体木質材の地域リサイクルシミュレーションモデルの構築 \\ DEVELOPMENT OF SIMULATION MODEL FOR RECYCLE OF WOODEN RESOURCE GENERATED IN DECONSTRUCTING HOUSES
}

\author{
野村希晶*, 有川智**, 福田展淳***, 小林均**** \\ Noriaki NOMURA, Satoshi ARIKAWA, Hiroatu HUKUDA \\ and Hitoshi KOBA YASHI
}

\begin{abstract}
A model for simulating the recycle process of wooden material produced by the deconstrucion of wooden houses has been developed, which is capable of describing the material flow of wooden resource based on logistic condition in a local area. The model, called recycle logistics model, consists of several agents which simulate wooden houses, deconstruction companies, intermediate process factories and recycle material production factories in the real world. They play their own role in computer program directed by political scenarios which control the material flow. An applied simulation for the recycle process in Yamaguchi Prefecture shows the useability and effectivness.
\end{abstract}

Keywords: Recycle, Simulation, Wooden resource, Deconstruction, Logistics

リサイクル，シミュレーション，木質資源，除却解体，ロジスティクス

\section{1. はじめに}

建築物の除却解体時に発生する廃棄物量は年々増加する傾向にあり， その再資源化を促すとともに建築活動から発生する廃棄物量を抑制す るための新しい技術と仕組みに対する社会的要望が高まっている。特 に木造建築物由来の建設発生木材は再資源化率が低迷しており，その 再資源化を促すための関連技術及びその普及基盤を早急に整備する必 要がある。循環型社会形成推進基本法をはじめとした関連 6 法の成立 により，我が国でも漸く廃棄物・リサイクル法体系が整備されつつあ る。それらの中には，再資源化に関する具体的な数值目標が示されて いるものも少なくない。例えば，平成 11 年 9 月ダイオキシン対策関 係閣僚会議において決定された「ダイオキシン対策推進基本指釬」で は, 平成 8 年度比での廃棄物減量化目標が定量的に示されている。即ち, 平成 22 年度までに, 産業廃棄物排出量の增加を $13 \%$ 削減, 再生利用 量を $42 \%$ から $48 \%$ に増加，そして最終処分量を半分に削減するとと もに，焼却量を $22 \%$ 削減するというものである。更に，平成 12 年 12 月には「建設りサイクル法に基づく基本方針」が策定され，建設発生 木材を含む特定建設資材廃棄物の平成 22 年度に扔ける再資源化・縮 減率を 95\%にするという数值目標が揭げられている。

これらの目標達成にあたっては，多様な再資源化ルート（例えば，
部材としての再使用，チップ化した上での再生利用（パルプ，パーデ ィクルボード等)，粉体化した上での再生利用（プラスティック化木材 等)，サーマルリサイクル等々が考えられるが，その組み合わせや比率 によって再資源化のあり方は大きく異なる。また，各ルートの需給バ ランスは地域によって異なり，再資源化を阻害している要因も一様で はない。これら多様な再資源化の問題に対応した技術・政策が求めら れているのであり，適正な再資源化の実現のために具体的な「リサイ クルシナリオ」を提示するとともに，その効果を定量的に検証する手 法の開発も求められている ${ }^{1)}$

\section{2. 研究の目的}

本研究は，木質系建築廃棄物の発生抑制技術の開発に関する基礎資 料とするために，現在そして将来に急増が予想される木質系建築廃棄 物について，マテリアルリサイクルや縮減などの処理内訳比率が各種 リサイクル施策によってどのように変化し，処理にかかわる輸送コス トがどのように変化するのかを量的に検討するモデルの開発を行った ものである。具体的には，木質系建築廃棄物のうち木造住宅（躯体非 木造を含む）の除却解体時に発生する廃木質材について，その除却以 降再資源化に至るマテリアルフローを地域内の道路輸送を条件として 定量的に追跡するモデルを構築し，様々な再資源化政策シナリオによ

\footnotetext{
* 東北大学大学院工学研究科建築・社会環境工学科 助教授 $\cdot$ 工博

**国土技術政策総合研究所住宅研究部 研究員・工博

*** 北九州市立大学国際環境丁学部環境空間デザイン学科 助教授. 言博

Assoc. Prof., Dept. of Architecture and Building Science, School of Engnr., Tohoku Univ., Dr. Eng.

Researcher, Housing Dept., National Institute for Land and Infrastructure Management, Dr. Eng.

Assoc. Prof., Dept. of Environmental Space Design, Faculty of Environmental Engnr., The Univ. of Kitakyushu, Dr. Eng.

EX CORPORATION Urban \& Environment Planning 
るシミュレーション計算を行い，地域内のマスバランス等の問題点を 抽出することを行っている。

本報は，今後目指すべき資源循環社会において，木造建築物の資源 循環が除却一生産の社会構造の中に量的にどう適用するかをシミェレ ーションによって明らかにしようとする端緒である。この問題はもと より国内全域の生産経済過程で考えるべきものであるが，現実的に検 証可能な範同を都道府県規模の地域に措定し，モデルに基づいた本手 法が有効性を持つかを吟味しょうとしている。

適正な資源循環を実現するためには，1）リサイクルプロセスにお けるマクロなバランス（出口と入り口の量的な整合性）一排出量と処 理可能量, 再生材料の供給と需要等, 2) 流通 (市場) のあり方（材料 を循環させるための前提条件）一-発生量・品質・立地（距離）・情報・ 経済的支援等一，3）近未来の時系列に沿った将来予測とその対応策一 建設年代による使用材料の変化・滅失戸数の推計に基-゙く除却量の予 測一，の観点からの検討が必要である。本研究では，てれらの検討事 項のなかから，特に 1) と2)についてモデル構築を行ったものである。

本論で示すような, 道路輸送を条件として廃木質材の好理をシミュ レートするモデルに関する研究はこれまで行われていないが，わが国 の木造住宅の $\mathrm{CO}_{2}$ 循環に着目し建設と除却をも考虑したパラメトリッ クモデル研究 ${ }^{2)}$ や建設業における物質のマテリアルフローを扱った研 究 ${ }^{3)}$ などが類縁の先行研究として挙げられる

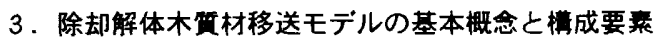 \\ 3.1 概要}

「都道府県」単位の地理規模を圈域と呼ぶことにする。本章では圈 域内で生じる住宅の除却解体時に発生する木質材料が，解体業者から 中間処理業者へ移送され中間処理業者から各種リサイクル上場あるい は縮滅丁場などへ移送される全プロセスをシミュレーションするもデ ルについて述べる。このモデルによって，ある圈域内での櫍資源の 処理能力の現状を把握し，資源循環政策が計画されたときその訤果を， 地域内での工場配置の特性や道路ネットワークの地理的条件から検討 することが可能になる。本モデルを地域リサイクルロジスティクスモ デル（以下ロジスティクスモデルまたはモデル）と呼ぶことにする。

\section{2 対象}

住宅建築の除却解体時には，建築生産物の特性から非常に多岐に渡 る材料が発生する。前章までに述べたようにこれらの中で今後も問題 になるものは特に櫍材料である。そこで，まず域内での木質材の資 源循環を取り上げることにする。しかし，本モデルの考え方で廃プラ スティックなど他の循環対象材料についても同様のシミュレーション は可能である。

また，廃木質材のうち特に除却解体に由来するものについてモデル 化を行う。廃木質材としては，新築工事由来あるいは土木工事由来の ものがあるが，これらについては本モデル内では表現していない。木 くず資源の総量を考えると，伐採木など土木工事由来の木質資源を加 味すべきと思われるが，それらの発生時期，発生位置が現状では将来 にわたって適正に予測できないので本研究ではモデルに取り入れるこ とを見合わせた。但し，新築工事由来の廃木質材は，ほぼ除却解体工 事と同等に扱えると思われる。あるいは，住宅除却解体件数と新築件 数の間に関係が見いだせれば，本モデルのシミュレーション結果を係 数倍することである程度は推定可能と思われる。
モデルで报っている廃木質材は住宅の除却由来の廃木質材なので結 果の解釈には注意を要する。例えば，後で述べる山口県のシミュレー ションでは, 山口県の木くず調査実績から除却解体由来の廃木質材が 総量の約 $1 / 3$ を占めた（2000 年度）という事実を考慮した上で結 果を吟味する必要がある。

\section{3 ロジスティクスモデルの概要}

地域内の住宅除却解体木質材の発生・移送及び処理に関わる地理的 及び人的事象について現象論的なモデル化を行った。モデル挙動の骨 格は以下のように述べることができる。域内で発生する住宅除却解体 木質材の解体·移送·処理に関係する実在の世界(実世界)の人や工場を, 属性と行為を持ったエージェントとして定義し，エージェント間で相 互に店答をやりとりする行為によって木質材は移送され，その移送前 後で分別された廃木質材，チップなどと形態が変化してゆく。その結 果域内の地理的に異なる場所に処理された木質材が蓄積されることに なる。エージェント間の応答のやりとりは時間軸にそって行われるの で離散的な時間ごとの挙動がシミュレーション結果として得られるこ とになる。

モデルをプログラムに実装する際には，各エージェントの属性は数 值情報や文字情報で表現される propertyとして, 行為や相互の応答は method として，これら propertyと method を有するエージェントは オブジェクトとして記述されることになる。以下では実世界のモデル 化という文脈ではエージェントと，モデルのプログラム記述という文 眽ではオブジェクトと呼ぶことにする。次節以降でロジスティクスモ デルの挙動を記述する基本要素のオブジェクトについて述べる。

\section{4 地域 - AREA オブジェクト}

各種地理的統計情報の入力と結果集計のための基本単位オブジェク トである。実際の解析対象県の市町村としてモデル化され，属性と変 数の夕を有し methodを持たないオブジェ.クトである。設定属性は表 1 に挙げたように，土地面積，人口と世带数，人口集中地区（DID）中 心位置座標，隣接 AREA との道路距離の情報などを保持している。また， この AREA オブジェクトそれ自体が後述する解体業オブジェクトと各 種処理丁場オブジェ.クトの属性にもなる。

表 1 地域オブジェクトの属性

\begin{tabular}{|c|c|c|}
\hline 地域情報 & 情報の型（単位） & 種別 \\
\hline ID コード & 整数 & 属性 \\
\hline 地域名 & 文字列 & 属性 \\
\hline 地域面積 & 実数 $\left(\mathrm{km}^{2}\right)$ & 属性 \\
\hline 世帯数 & 整数 (世帯) & 属性 \\
\hline 地域人口 & 整数（人） & 属性 \\
\hline 人口集中地区の広がり & 実数 & 属性 \\
\hline 人口集中地区中心 $\mathrm{x}$ 座標 & 実数 $(\mathrm{km})$ & 属性 \\
\hline 人口集中地区中心 y 座標 & 実数 $(\mathrm{km})$ & 属性 \\
\hline 圈域内世带率 & 整数 & 属性 \\
\hline 平均住宅齢 & 整数（年） & 属性 \\
\hline 除却総床面積 & 実数 $\left(\mathrm{m}^{2}\right)$ & 変数 \\
\hline 木造家屋率 & 実数 & 属性 \\
\hline 除却数 & 整数 & 変数 \\
\hline 除却率 & 実数 & 変数 \\
\hline 無効除却発生数 & 整数 & 変数 \\
\hline 隣接地域数 & 整数 & 属性 \\
\hline 隣接地域間距離 & 実数 $(\mathrm{km})$ & 配列変数 \\
\hline 隣接地域コード & 整数 & 配列変数 \\
\hline 地域内解体業者数 & 整数 & 属性 \\
\hline
\end{tabular}




\section{5 解体業 - WRECKER オブジェクト}

地域内で発生した除却家屋を分別解体する解体業をモデル化したオ ブジェクトである。除却対象住宅の延床面積と建築年から, 軸材, 面 材を各自の業務能力に忘じて分別し，政策シナリオに従い，地理的条 件（ロジスティクス）を考慮して各種中間処理工場に移送する働きを 有する。このオブジェクトの有する属性は表 2 に示した通りである。

\section{6 中間処理工場ーIMPF オブジェクト}

解体業オブジェクトの解体木質材の処理受け入れを意思決定し, 移送された解体木質材を切削，破砕，粉体化，樎減などのいずれ かの処理を行う中間処理施設をモデル化したオブジェクトである。 IMPF(Intermediate Process Factory) と略称する。実際の中間処理には その後の製品化や減容化に応じた各種の処理様態が存在するが, 現在 のわが国の解体材の処理を現実的な範囲で表現できるものとして，本

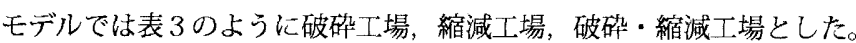
破砕工場は特に縮減用チップ化とボード用チップ化に分けた。また, 地域内ロジスティクスの政策シミュレーションのために，実際には存 在しないが分別資源を蓄積・再配分する新しいタイプの中間処理工場 （共同集積場と呼ぶ）を設けた。これら，中間処理工場オブジェクトが 有する情報を表 4 に示した。

\section{7 製品化工場一 RCY オブジェクト}

中間処理工場で処理されたヂップなどを受け取る工場を表現したオ ブジェクトである。RCY (Recycle Factory) と略称する。中間処理に は木質ボードなどリサイクル製品用のチップを生成する場合と，焼却

\section{表 2 解体業オブジェクトの属性}

\begin{tabular}{|c|c|c|}
\hline 解体業情報 & 情報の型 (単位) & 種別 \\
\hline ID コード & 整数 & 属性 \\
\hline 所属地域コード & 整数 & 属性 \\
\hline 所在位置 $\mathrm{x}$ 座標 & 実数 $(\mathrm{km})$ & 属性 \\
\hline 所在位置 y 座標 & 実数 $(\mathrm{km})$ & 属性 \\
\hline 除却処理速度 & 実数 $\left(\mathrm{m}^{2} /\right.$ 日) & 属性 \\
\hline 除却処理精度 & 実数 & 属性 \\
\hline 平米あたり解体単価 & 実数 (円 $\left./ \mathrm{m}^{2}\right)$ & 属性 \\
\hline 解体中家屋コード & 整数 & 変数 \\
\hline 除却待ち家屋数 & 整数 & 変数 \\
\hline 除却待ち家屋コード & 整数 & 配列変数 \\
\hline 累積移送支出 & 実数 $($ 円 $)$ & 変数 \\
\hline 解体材処理費 & 実数 $\left(\right.$ 円 $\left./ \mathrm{m}^{3}\right)$ & 変数 \\
\hline 累積解体収入 & 整数 (円) & 変数 \\
\hline 中間処理工場との取引のタイプ & 文字列 & 属性 \\
\hline 親取引中間処理業工場数 & 整数 & 変数 \\
\hline 親取引中間処理業工場コード & 整数 & 配列変数 \\
\hline 中間処理工場取引緊密度 & 実数 & 配列変数 \\
\hline 近距離中間処理工場数 & 整数 & 変数 \\
\hline 近距離中間処理工場コード & 整数 & 配列変数 \\
\hline 解体終了状態フラグ & 論理 & 変数 \\
\hline 搬出待状態フラグ & 論理 & 変数 \\
\hline 解体中状態フラグ & 論理 & 変数 \\
\hline 受注待状態フラグ & 論理 & 変数 \\
\hline
\end{tabular}

表 3 中間処理工場の種類

\begin{tabular}{|c|c|}
\hline 記号 & 工場種類 \\
\hline $\mathrm{C}$ & 縮減用チップ工場 \\
\hline C-RCY & 製品用チップ工場 \\
\hline $\mathrm{R}$ & 縮減工場 \\
\hline $\mathrm{C} \& \mathrm{R}$ & チップ化後縮減工場 \\
\hline C\&R-RCY & 製品用チップ工場（有焼却炉） \\
\hline SEP & 共同集積場（仮想工場） \\
\hline
\end{tabular}

用チップを生成する場合があり，後者の場合は引き続いて縮減のため の焼却中間処理工場やサーマルリサイクル用の処理工場に処理チップ が移送される。縮減された処理物は最終処分場へと移送されるが本モ デルではその移送プロセスや最終処分場との需給関係は取り报わず, 繀減化された処理物はその工場に留め置いてマスバランスを計測する ものとした。

RCYは，リ将用のチップなどを受け取るオブジェクトでこれ 以上の木質材の流れは追わないモデルの境界に相当している。言い換 えれば，境界の外部にある経済とのやりとり，すなわち生産や出何な どは行わず，木質材移送物の最終保持状態を計量するためのオブジェ クトである。したがって，処理能力などはオブジェクトの属性として 考慮せず，移送チップは全て処理タイプに応じた製品化がなされると 見なしている。RCY オブジェクトでは，全地域内の立地条件の影響を 調べるうえで位置座標とストック量のみが主要な属性になる。モデル に実装された処理タイプすなわち製品化工場の種類は，実世界ではバ イオマス発電所などに相当するサーマルリサイクル工場，マテリアル リサイクルとしてのボード工場, 近い将来開発と流通が期待される構 造用部材を生産する高付加価值型材料工場, およざ製紙工場である（表 5)。これらの工場の配置条件を変えることで解体木質材の地域内移送 を調べることができる。

\section{8 解体住宅-HOUSE オブジェクト}

以上の他に，それ自身の挙動は受動的で他に働き掛ける影響が少な いが必要な構成要素として，解体される住宅のオブジェクトを表 60

表 4 中間処理工場オブジェクトの属性

\begin{tabular}{|c|c|c|}
\hline 中間処理工場情報 & 情報の型（単位） & 種別 \\
\hline ID コード & 整数 & 属性 \\
\hline 工場名 & 文字列 & 属性 \\
\hline 処理工場タイプ & 文紊列 & 属性. \\
\hline 所属地域コード & 整数 & 属性 \\
\hline 所在位置 $\mathrm{x}$ 座標 & 実数 $(\mathrm{km})$ & 属性 \\
\hline 所在位置 y 座標 & 実数 $(\mathrm{km})$ & 属性 \\
\hline 処理能力速度 & 実数 (ton/日) & 属性 \\
\hline 処理効率 (歩留り) & 実数 & 属性 \\
\hline 末処理ストックヤード(面材 & 実数 $\left(\mathrm{m}^{3}\right)$ & 変数 \\
\hline 未処理ストックヤード（軸材） & 実数 $\left(\mathrm{m}^{3}\right)$ & 変数 \\
\hline 処理後ストックヤード & 実数 (ton) & 変数 \\
\hline 受入処理費 & 整数 (円) & 属性 \\
\hline 処理材有価值 & 整数 (円) & 属性 \\
\hline 取引型 & 文字列 & 属性 \\
\hline 累積受託妈理費 & 整数 (円) & 変数 \\
\hline 累積処理費 & 整数 (円) & 変数 \\
\hline 累積移送費 & 整数 (円) & 変数 \\
\hline 得意先処理工場数 & 整数 & 変数 \\
\hline 得意先処理工場コード & 整数 & 配列変数 \\
\hline 接続中間処理工場数 & 整数 & 変数 \\
\hline 接続中間処理工場コード & 整数 & 配列変数 \\
\hline 接続中問処理工場距離 & 企数 $(\mathrm{km})$ & 配列変数 \\
\hline 接続地域数 & 整数 & 属性 \\
\hline 接続地域 DID 中心との距離 & 実数 $(\mathrm{km})$ & 配列変数 \\
\hline 接続地域コード & 整数 & 配列変数 \\
\hline
\end{tabular}

表 5 製品工場の種類

\begin{tabular}{|l|l|}
\hline 記号 & 工場種類 \\
\hline$B D$ & ボード工場 \\
\hline THML & サーマーレリサイクル工場 \\
\hline EWD & 高付加価值型材料工場 \\
\hline PMF & 製紙工場 \\
\hline
\end{tabular}


表 6 解体住宅オブジェクトの属性

\begin{tabular}{|c|c|c|}
\hline 解体住宅情報 & 情報の型 (単位) & 種別 \\
\hline ID コード & 整数 & 属性 \\
\hline 所属地域コード & 整数 & 属性 \\
\hline 地域域内位置距離偏差 & 実数 $(\mathrm{km})$ & 属性 \\
\hline 建築齢 & 整数（年） & 属性 \\
\hline 初期床面積 & 実数 $\left(\mathrm{m}^{2}\right)$ & 属性 \\
\hline 構法種コード & 文字列 & 属性 \\
\hline 解体中残り床面積 & 実数 $\left(\mathrm{m}^{2}\right)$ & 変数 \\
\hline 除却木質材 (軸材) & 実数 $\left(\mathrm{m}^{3}\right)$ & 変数 \\
\hline 除却木質材（面材） & 実数 $\left(\mathrm{m}^{3}\right)$ & 変数 \\
\hline
\end{tabular}

ように設けている。シミュレーション計算では，AREA オブジェクト によって生成され，その状態を表す解体中残り床面積（解体前は初期 床面積と等しい）が単位時間（日）にWRECKER オブジェクトによっ て減少させられ（解体され），除却木質材（軸材）と除却木質材（面材） が増加することになる。

\section{4. ロジスティクスモデルの挙動}

前章に述べたオブジェクトが, 与えられた政策シナリオと自己の能 力に基づいて，関連する他のオブジェタトと情報をやりとりしながら 行動し，自分の状態と関連オブジェクトの状態を単位時間中に変化さ せることが，シミュレーション計算の実体である。本章では，各オブ ジェクトの挙動の詳細について述べる。ここでの各挙動は単位時間 (実 際のシミュレーションでは日単位)に扎けるものである。

\section{1 地域オブジェクトの挙勤}

AREA オブジェクトには，圈域全体で得られている実際の除却床面 積の総和が世帯数比にしたがってシミュレーション開始前に分配され る。単位時間中には各 AREA オブジェクトは正規乱数で除却休面積を 発生し，平均家屋床面積で除してその整数商を当単位時間の必要除却 家屋数とする。したがって，世带数の少ない地域には必ずしも毎単位 時間に除却家屋が発生することにはならないようになっている。

除却確率は，除却家屋予測モデルによって与えるべきものだが，本 研究の目的の範囲を超えること, また, 地域毎の除却家屋予測自体が 精度の観点からは困難な課題になるので，本モデルでは除却家屋総床 面積が圈域の 1 年間の実統計量に合致するように除却を発生させるも のとした。

必要除却家屋は以下の規則にしたがって当該地域内の WRECKER オ ブジェクトに割り当てられる。

（1）現在解体物件を持たないWRECKER オブジェクトに割り当てる。

（2）解体単価が小さい順に割り当てる。

（3）解体単価が同じ場合はランダムに割り当てる。

（4）以上でも割り当てられない場合は, 単価の小さい順にランダムに

WRECKER オブジェクトの除却待ち行列に割り当てる。

\section{2 解体業オブジェクトの挙動}

4.1 のように必要除却家屋を割り当てられた WRECKER オブジェ クトは以下の規則にしたがって, 地域内必要除却家屋の分別解体と中 間処理工場への移送を行う。

（1）単位時間当りの作業能率と作業精度にしたがって, 当該除却家

屋の床面積から，柱梁などの軸材と壁や下地などの面材を生成する (解体する)。その生成割合は, 除却住宅の種別毎の平均的な構成比 にしたがうものとする。

（2）当該除却住宅の床面積がゼロになった時点で, 次の時間ステップ
から移送処理に移行する。実世界の解体では, 解体作業と移送作業 が同一日に行われる場合もあるが，そのような作業工程でも解体終 了後移送をまとめて行う工程でも，総作業量で見るとモデルの全体 結果に及ぼすような大きな差はないと考えられるので，モデルでは ミクロな解体作業の記述はしていない。

（3）解析時に設定した政策シナリ才（後述）を遵守しつつ，解体材を 移送する中間処理工場（IMPF オブジェクト）を探す。この際，処 理費の低いものから探し，処理費が同じ場合は移送距離の小さい方 を優先する。

（4）IMPF オブジェクトが受け入れを受諾した場合にはそこへ解体材 を移送する。受け入れを拒否された場合には（3）を繰り返す。

以上の処理は, 各地域毎に全 WRECKER オブジェクトがとる行動だ が, 計算時の䘕動順序は毎時間ランダムに変えることで, 結果の平等 性を確保している。

WRECKER オブジェクトが悪意を持った行動をとることは全く考え られていないので，建設リサイクル法に従って $50 \mathrm{~km}$ 圈内に中間処理 工場を探索し，見つかった場合でそこが受け入れを受諾した時は，た とえ移送費は大きくなっても解体材は必ずそこへ運ぶことになる。し たがって，いわゆる不法投棄などは発生しない。しかし，解析時に 与えた IMPF のストックヤードや処理能力の值しだいでは行き先の ない解体材も計算上は発生する可能性がある。この場合の解体材は， HOUSE オブジェクト内に残ったままになる。現集には，中間処理工場 の空きを待ったりして移送先を探し続けるものだが，圈域内の中間処 理工場の総処理能力の評価や不法投暂の可能性評価のために, HOUSE オブジェクトに解体材が残る現象を許すことにしている。

\section{3 中间処理工場の挙動}

IMPF の行動は，工場の種類によらず共通なものと，工場の種類に よって異なるものがある。工場の種類によらない共通な行動規則は以 下゙の通りである。

（1）WRECKER オブジェクトから解体材の处理要求があった場合に, ストックヤードの限界量以内であればそれを受け入れ，限界量を超 える場合は拒否する。

（2）ストックヤードにある解体材を, 自己の処理能力に応じて処理し， 備蓄ヤードに蓄える。

（3）備蓄ヤードにある処理材（チップなど）を，政策シナリオを遵守 しつつ次の処理工場に，処理費の低い順で移送距離の小さい順に選 抧し移送する。

工場の種類別では以下の行動規則に従う。

（1）C（縮減用チップ工場）：移送先は縮減工場かサーマルリサイク ル丁場である。

（2）C-RCY (製品用ヂップ工場），C\&R-RCY（有焼却炉）：移送先は縮 減工場とサーマルリサイクル工場以外である。C\&R-RCY は歩留り以 外の残余の焼却処理を行う。

（3） R (樎減工場）: 次の処理工場はないことにする（前述の最終処 分の报いによる)。

（4）C\&R（チップ化後縮減工場）：サーマルリサイクル優先シナリオ が採られていない場合には自社で縮減処理まで行う。次の処理工場 はないことにする（前述の最終処分の报いによる）。

（6）SEP (共同集積場）：解体材の処理を行わず，備蓄ヤードから解 体材を,製品用チップ工場のうち予め決められている得意先工場（共 同集積の契約工場）へ再配送する。 


\section{4 全体挙動の記述と評価量}

以上の各オブジェクトの行動によって, 解体木質材が各種処理を 受けて，圏域内を移動することになる。これらの量的変化は，単位 時間の変化量が各種オブジェクトの各種属性として与えられているの で，一階差分を前進的に解くことになる。モデルの全体挙動の骨格部 分は，各オブジェクトの相対的位置関係から計算される道路距離評価 に基づく行動決定関係とその間の木質材移送にある。そしてこれらを 制約したり, 助長したりする政策シナリオが関数記述として表現され ている。

モデルからの出力は，木質材の各種処理量と移送コストの地理分布 と時系列である。除却解体は実際の一棟一棟を数值的に発生させてお り, 何十年単位での挙動を想定していない。現状との比較のために単 年解析が中心になるので, 季節条件が染刻な地域でないかぎり時系列 はあまり意味を持たず，年間総量が重要な出力結果となる。また，モ デルの表現精度に比べ，与えているパラメータの情報精度が低いので， 出力量はオーダー程度で吟味するものとし, 解析パラメータの違いに よる出力量の構成比に着目するべきと考える。

以上のような挙動をシミュレートし必要なパラメータ設定と入出力 を行うコードをプログラム開発した。図1はそのメインインターフェ イスである。

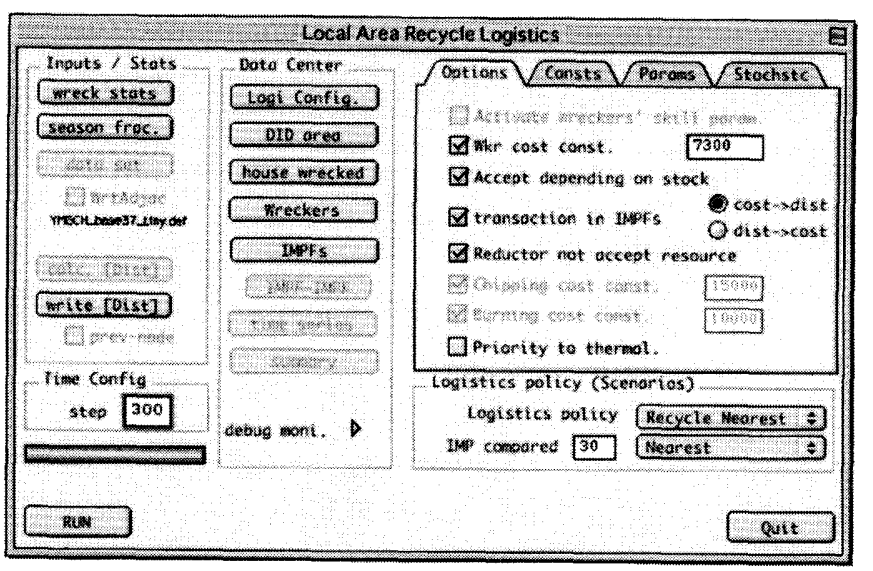

図 1 シミュレーションプログラムメインインターフェイス

表 7 設定政策シナリオ

\begin{tabular}{|c|c|}
\hline 記号 & 内容 \\
\hline Base & 現涀をシミュレーションするもの \\
\hline Dxn & $\begin{array}{l}\text { ダイオキシン類対策特別措置法扔よび改正廃棄物処理 } \\
\text { 法に基づきダイオ名场 } \\
\text { 除外した場合 }\end{array}$ \\
\hline RcyThrml & $\begin{array}{l}\text { 縮減用チップ工場にその移送先としてサーマルリサイ } \\
\text { クル工場を優先させる }\end{array}$ \\
\hline RcyForce & 解体木質材を製品用チップ工場へ優先移送する場合 \\
\hline RcySep & $\begin{array}{l}\text { 解体木質材を共同集積場に優先移送し，共同集積場が } \\
\text { 特定の製品化工場に契約接続する場合 }\end{array}$ \\
\hline
\end{tabular}

上記で「優先」という意味は，道路距離 $50 \mathrm{~km}$ 圈内に対象移送先があ る場合は必ずそこへ移送することを指す

\section{5. 政策シナリオの設定と適用事例}

\section{1 政策シナリオ}

4 で述べたように，WRECKER オブジェクトの解体木質材移送と IMPF オブジェクト間の処理材移送は，各オブジェクトに内在しない政 策的な誘導，すなわち政策シナリオに従うことが決められている。ま た，この政策シナリオによって，圈域内の住宅除却由来木質材のマス バランスの違いや移送コスト変動を検討することが本モデルの目的で もある。政策シナリオのあり方は，法的な論拠と木質資源の市場価值 を勘案して定められるもので，論理的な設定法が求めにくいものであ る。本研究ではモデルの表現力・記述力をはかる目的で，ある程度妥 当と考えられる5つの基本シナリオを表 7 のうに定めた。このうち, RcySep は政策シナリオは他の現実的なシナリオとは異なり，政策が新 たな工場立地を誘導したもので対象圈域の将来のリサイクルネットワ 一クの理想像のひとつを形にしょうとしたものである。

これらのシナリオは計算プログラムではオブジェクトがとる行動の 関数によって実装されている。また，同一のシナリオでも，後述の表 9 に示叶計算パラメータや定数の設定の組合せで多様な表現ができる ようになっている。

\section{2. 適用対象概要}

本ロジスティクスモデルは多くの計算パラメータの設定が必要であ り，実在のわが国の都道府県において当てはめるためには，ある程度 調査資料が充実している圈域を選定する必要がある。本研究で選定し た圈域は山口県である。ここは，国内ではリサイクル政策への取り組 みが先進的な自治体のひとつで，モデル適用対象として統計資料も充 実している ${ }^{4)}$ 。そこで既存の統計資料に独自の調查を加えて本モデル の計算パラメータを設定し, 山口県の解体木質材のロジスティクスシ ミュレーションを行った。

\section{3 山口県モデルパラメータ}

山口県の統計資料抢よび調査資料からロジスティクスモデルに与え た基本条件は表 8 の通りである。各オブジェクトには 3 章で述べた属 性が付与されている。AREAオブジェクトには統計資料に基づいて属 性を与えた。但し, DID 中心は各市町村の行政中心とした。また, 隣 接市町村間のネットワークは, 地図上の県道以上の主要道路の接続関 係から道路距離を測って与えている。

WRECKER オブジェクトについては, 解体業者の統計実態がほとん ど不明で総数も未知である。そこで, 計算時に発生除却家屋が地域内 の WRECKER オブジェクトに割り当てられればよいとし, WRECKER オブジェクトの待ち行列に数件以内で納まる程度の解体業者数を想定 した。結果的には必要解体業者総数は県内工務店数の 3 分の 1 ぐらい になり，これを地域の人口比に応じて地域内に一様に分布させた。また, 同様の理由から WRECKER オブジェクトの属性は全て一律にした。し たがって，本解析では WRECKER オブジェクトの個々の特性は捨象さ れている。

中間処理業のモデルでの取り报いを述べておく。収集した山口県 の中間処理施設データで, 能力や施設位置などがはっきりしているも

表 8 山口県モデル基本データ

\begin{tabular}{|c|c|c|c|c|c|c|c|}
\hline \multirow{2}{*}{$\begin{array}{l}\text { AREA オブジェクト } \\
\text { 住宅除却総床面積 }\end{array}$} & \multicolumn{7}{|c|}{56 県内市町村数 } \\
\hline & \multicolumn{7}{|c|}{ 木造 $665000 \mathrm{~m}^{2}$, 非木造 $323000 \mathrm{~m}^{2}$ (2000 年実績) } \\
\hline WRECKER オブジェクト & \multicolumn{7}{|c|}{2199 仮定総解体業者数（市町村に人口比で配分） } \\
\hline \multirow[t]{3}{*}{ IMPF オブジェクト } & 種類 & $\mathrm{C}$ & C-RCY & $\mathrm{R}$ & $C \& R$ & C\&R-RCY & 計 \\
\hline & \multirow{2}{*}{$\begin{array}{l}\text { ダイオキシン対応前 } \\
\text { ダイオキシン対応後 }\end{array}$} & 18 & 10 & 27 & 9 & 10 & 74 \\
\hline & & 18 & 10 & 14 & 6 & 7 & 55 \\
\hline
\end{tabular}




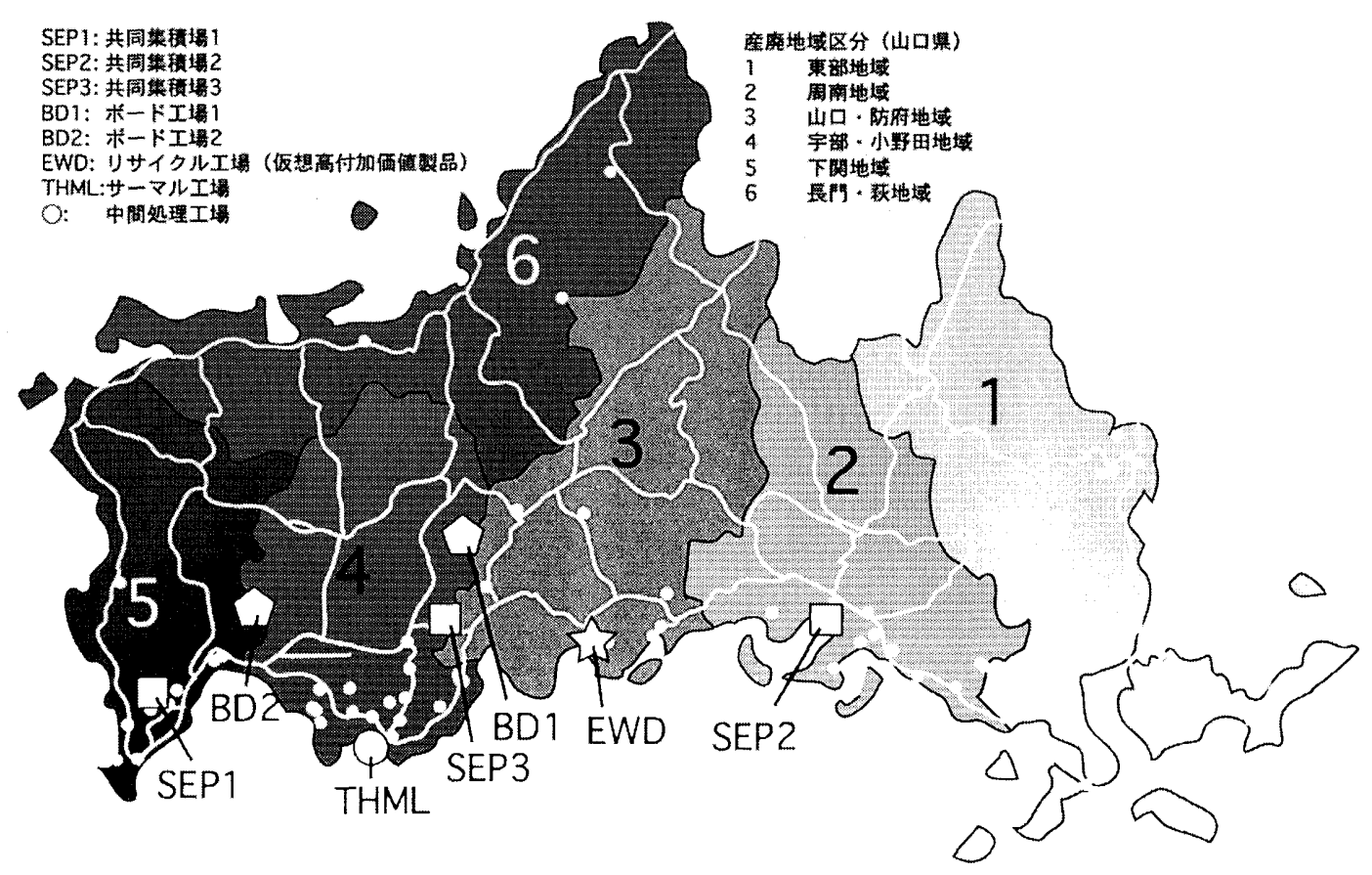

図 2 山口県圈域概要

産廃 6 地区区分（図注潘多），主要道路㧍よびシミェレーションに用いた主要な各種処理工場

表 9 シミュレーションに用いた計算パラメータ

\begin{tabular}{|c|c|c|}
\hline 名称 & 内容 & 值 \\
\hline 軸材率 & 家屋分別解体時に軸材の占める割合 & $0.179 \mathrm{~m}^{3} / \mathrm{m}^{2}$ \\
\hline 面材率 & 家屋分別解体時に的材の与ぬる割合 & $0.066 \mathrm{~m}^{3} / \mathrm{m}^{2}$ \\
\hline かさ比重 & 解体木質材の)好かけ比重 & 0.205 \\
\hline 稼働時間 & 什間処理施設山平均稼働時間 & 10 hours \\
\hline 減容率 & 燒却樎減時体積現象割、令 & $95 \%$ \\
\hline 政策移送距離限界 & 政策シナーリオに従う最大移送距離 & $50 \mathrm{~km}$ \\
\hline 解体材移送費 & 解体業の除却木質材平均移送費用（4トントラック） & 10000 円 $/ 25 \mathrm{~km}$ \\
\hline チップ移送費 & 中間処理士場のチップ平均移送費用 & 53 円 $/ \mathrm{km} / \mathrm{ton}$ \\
\hline プレストック量 & 中間処理施設末処理材蓄積可能量 & 28 日分処理量 \\
\hline 除却家屋床変動 & 住宅平均面積の変動係数 & 0.2 \\
\hline 除却家屋日変動 & 日当り除却発生率の変動係数 & 0.1 \\
\hline
\end{tabular}

の，あるいはそれらが仮定できるものの数は 74 施設である。これら の施設の処理の種類は, 調查結果によれば（1）破砕，(2) 焼却，(3) 破研と焼却である。しかし，ヂップ化工場でも，実際にリサイクル原 料として製品化工場へ売却しているか，縮隇用チップとしているかな どの実態は全ての施設について分かってはいない。また，処理後の移 送先も分かっているものはわずかである。従って, シミュレーション データとしては，製品用チップとしてリサイクル工場へ販売している ことがわかっている場合以外のチップ工場は焼却縮減している場合が 多いと考えられるので堯却用として报った。

表 8 のダイオキシン対応工場数は基本的には調査結果に従ったが, 調査回答が不明の煃却工場は, 全て未対念として报った。また, 山口 県には焼却処理能力が極めて高いセメント工場が存在するが，実際の 受け入れはあまり行われていないこと，また，これを考慮すると影響 が強すぎるので报わないこととした。

山口県内の産廃地域 6 区分（山口県独自の定義による）と IMPFを 図2に示した。また, これらがシミュレーション時に表示された一例 を図３に示した。図３でネットワークは直線で表わされているが，プ

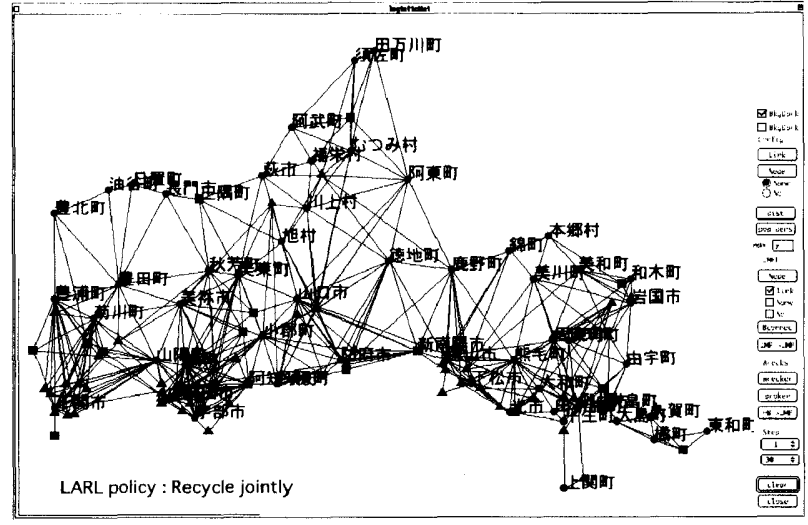

図 3 シミュレーションプログラムでのネットワーク表示

ログラム内部のリンク距離は直線距離ではなく地図上の道路距離を測 定して与えた。

5.4 政策シナリオと計算パラメータ

山口県の平成 12 年度（2000 年度）実績の県内木くず発生量が報 
表 10 山口県産廃地域每の除却木筫材発生量

\begin{tabular}{|l|l|c|c|c|}
\hline 地区番号 & \multicolumn{1}{|c|}{ 地区名 } & $\begin{array}{c}2000 \text { 年度害績 } \\
<\text { ton }>\end{array}$ & $\begin{array}{c}\text { 計算值 (変動係数) } \\
<\text { ton }>\text { 計算值 /実績值 }\end{array}$ \\
\hline 1 & 東部地域 & 10831 & $8941(0.008)$ & 0.83 \\
\hline 2 & 周南地域 & 7767 & $8631(0.007)$ & 1.11 \\
\hline 3 & 山口・防府地域 & 10830 & $10016(0.009)$ & 0.92 \\
\hline 4 & 宇部・小野田地域 & 10904 & $9481(0.007)$ & 0.87 \\
\hline 5 & 下関地域 & 9493 & $9662(0.007)$ & 1.02 \\
\hline 6 & 長門・萩地域 & 5366 & $3808(0.009)$ & 0.71 \\
\hline & 県全体 & 55191 & 50539 & 0.92 \\
\hline
\end{tabular}

告されている。この統計量と比較しうる基本解析を行った後に，各種 政策シナリオを設けてシミュレーションを行った。設定したシナリオ は表 7 に示したものを用いたが，シナリオ Base は統計量が存在する 2000 年度の山口県を対象とした。また，シナリオ RcySep として,

1) RcySep 1：下関近郊に仮想共同集積場（図 2 のSEP1）を設け, 契約工場として近傍の 4 箇所の製品用チップ工場（図中○印）に接 続した場合

2) RcySep2：仮想共同集積場を下関近郊と徳山近郊に 2つ（図 2 のSEP1，SEP2）設けて，そのそれぞれが近傍 4 䇢所の製品用チッ プ工場を契約工場として持つ場合

3）RcySep3：防府市付近（瀬戸内海側の県中央部）に高付加価值 型材料を想定して新規に RCY 工場オブジェクトを配置し（図 2 の EWD），共同集積場を 3 筒所にした場合（SEP3を追加）

を設定した。

モデル境界の意味を持つ製品工場は距離計算上はダミ一的であるの で県の人口重心に近い位置に設けた（図 2 の BD1）。但し，シナリオ RcySep 3 では EWD 工場（図 2 の EWD）と距離を扔くためにその位 置を移動させた（図 2 の BD2）。また，製紙工場（PMF）は山口県の シミュレーションでは用いていない。

表 9 は本解析で計算に用いた計算パラメータの主要なものである。 計算は 1 年を 300 日として行った。

\section{5 シミュレーション結果と考察}

\section{（1）基本解析結果}

表 10 に計算と調査実績の比較結果を示す。シミュレーション計算 では, 発生除却面積やオブジェクトの行動順序など事象の発生を確率 的に与えている点が数多くある。従って，基本解析では 10 回の計算 を行いその平均值で結果を検討している。AREA（市町村）毎に計算が 実行されているので，表のように産廃地域（山口県が設定したもの） 毎にシミュレーション結果をまとめることが可能である。シミュレー ションパラメータとして与えている実資料は, 年間総除却面積だけで あるので, 表 10 のよう計算值 / 実績値がおおむね 1.0 前後におさま っていることから，モデルのマクロな精度としては充分であると思わ
れる。地域毎に 1.0 のまわりにばらつくのは，モデルでは総除却面積 を各 AREAに人口比で割り当てているのに対し，実情はAREA 毎の除 却発生に偏りがあるためと思われる。県全体の総除却木質材発生量は 計算／実績 $=0.92$ であった。計算值が小さいのは，モデルの解析時間 が実態より小さくなっている可能性があること（工場稼働時間 8 時間, 週末休止を仮定して計算)，分別解体の解体率や歩留りの設定，解析終 了時点で未解体家屋が存在することなど複数の要因によるものと思わ れる。解析時間の調整で計算值を実績值に恣意的に近づけることは可 能だが, 現段階では家屋解体処理現状全般の高精度な再現は目標にし ていないので，表 10 の結果はマク口な量的検証として充分なものと 判断した。

\section{（2）政策シナリオ解析結果}

表 11 に，各種政策シナリオのシミュレーション結果を，処理内訳 と移送コスト比としてまとめた。基本解析の結果，変動係数が極めて 小さいことが分かったので, 各政策シナリオの解析では 5 回の計算の 平均值を求めた。

コスト比は製品化テップエ場とリサイクル工場間の移送コスト（記 号：C-Rcy），焼却用チップ工場と焼却工場間の移送コスト（記号： C-R），共同集積場とリサイクル用チップ工場間の移送コスト（記号： Sep-C，シナリオ RcySep1, RcySep2, RcySep3 の場合）および解体業か ら各種中間処理工場への移送コスト（記号：wrecker）の総和を，基準 移送コスト（シナリオ Base の C-R のコスト值及びとシナリオ Base の wreckerのコスト值）の比で表している。

計算プログラム内部では, 解体費, 処理費, チップ売却費も計算し ているが，実情のデータが非常に粗いので，オブジェクトの行為をコ ストで決定するシミュレーション方略はかえって挙動の不整合を引き 起こしやすい。したがって，実際には動的に変化する諸単価を一律に 扱い，上述のように距離に基づいた移送コストの比率を考察対象とし た。設定した各シナリオから得られた知見は次のようにまとめられる。

（a）シナリオ Base：これは 2000 年現状のうち，家屋除却解体由来 分の廃木質材の処理を見たものだが，ほぼ $1 / 3$ のマテリアルリサイク ル率になり，これは山口県の全木くずの処理現況と対応している数值

表 11 各種政策シナリオ毎のシミュレーション結果

\begin{tabular}{|c|c|c|c|c|c|c|c|c|c|c|c|c|}
\hline \multirow{2}{*}{$\begin{array}{l}\text { シナリオ } \\
\text { 記号 }\end{array}$} & \multicolumn{8}{|c|}{ 処理内訳（\%） } & \multicolumn{4}{|c|}{ 移送コスト比 } \\
\hline & $\begin{array}{l}\text { マティアル } \\
\text { リサイクル }\end{array}$ & $\begin{array}{l}\text { サーマル } \\
\text { リサイクル }\end{array}$ & $\begin{array}{l}\text { 高付加価 } \\
\text { 值材 }\end{array}$ & 縮減 & 破砕待 & 縮減待 & 移送待 & waste & C-Rcy & $\mathrm{C}-\mathrm{R}$ & Sep-C & wrecker \\
\hline Base & 34.9 & & & 55.3 & 1.3 & 4.3 & 0.3 & 3.9 & 2.90 & 1.00 & & 1.00 \\
\hline $\mathrm{Dxn}$ & 32.0 & & & 44.4 & 2.2 & 4.4 & 12.7 & 4.4 & 2.19 & 2.72 & & 1.14 \\
\hline RcyThrml & 30.3 & 62.9 & & 0.0 & 2.2 & 0.0 & 0.3 & 4.2 & 1.87 & 8.89 & & 1.13 \\
\hline RcyForce & 94.6 & & & 0.8 & 1.5 & 0.0 & 0.3 & 2.8 & 6.62 & 0.02 & & 1.59 \\
\hline RcySep 1 & 52.8 & & & 36.4 & 2.9 & 3.5 & 0.4 & 4.1 & 3.46 & 1.06 & 0.82 & 1.76 \\
\hline RcySep2 & 81.9 & & & 11.9 & 2.5 & 0.6 & 0.3 & 2.7 & 6.27 & 0.36 & 4.00 & 2.40 \\
\hline RcySep3 & 33.6 & & 50.4 & 10.4 & 1.7 & 0.6 & 0.3 & 3.0 & 3.32 & 0.34 & 4.07 & 1.82 \\
\hline
\end{tabular}


となった。

（b）シナリオ Dxn：ダイオキシン非対応処理場を除くことにより， マテリアルリサイクル分はあまり変化しないが縮隇量が減り焼却工場 への移送待ち量が増加している。モデルで报っている対象が解体工事 由来の廃木質材で, 山口県の現実はその 2 倍の処理量が要求されてい ることを考えると，焼却場不足は明らかである。また，処理されてい るものも，対応以前の 3 倍弱の移送コスト（C-R）がかかっている。

(c) シナリオ RcyThrml：縮減にまわる廃木質材を $50 \mathrm{~km}$ 圈内にサ 一マル工場がある場合はそちらへ移送するという政策を取ると，全樎 隇量とマテリアルリサイクルの一部がサーマルリサイクルにまわった 結果となる。ただし，処理工場からサーマル工場への移送コスト (C-R) が大きく増大することは避けられない。

（d）シナリオ Rcy-Force:全て製品用チップ化することを強制すると， 解体から製品用チップ工場へ移送するコストが約 1.6 倍になる。また 製品用チップ工場からの移送コストも増大している。このときのチッ プ供給量は約 46000 トンで過剩供給が心配される。またこの結果は, 山口県で縮減分を全て製品用チップに移行させようとしてそれができ るだけのチップ工場の総能力があるということも意味している。

（e）シナリオ RcySep1：下関に仮想共同集積場を設けて製品用チッ プ工場と 4 籄所と接続した場合, 縮隇量が約 $19 \%$ 減少し，その分のマ テリアルリサイクルが增加する。この場合，解体業者の共同集積場へ の移送コスト増が生じ 1.8 倍になる。

（f）シナリオ RcySep2：下関と徳山にそれぞれ仮想共同集積場を設 けて製品用チップ工場とそれぞれ 4 籄所接続した場合，山口県の除却 木質材がほとんど配送圈内に入るので，マテリアルリサイクルが 8 割 以上に上昇する。リサイクルの観点から見ると好ましく思えるが，実 際にはチップの過剩供給に陥る可能性があり必ずしも有効な政策とは 限らない。また，共同集積場からの移送コストは，徳山の共同集積場 とこれに接続する処理場の距離が遠いため，上昇している。また，共 同集積場が増えたことで，解体移送コストも上昇する。

（g）シナリオ RcySep3：意図的に防府市付近に構造材などに使用可 能な高付加価値型材料を想定して新規に RCY 工場オブジェクトを配置 した場合である。また，共同集積場配置はシナリオ RcySep1, RcySep2 の結果からみてわかるように，人口集中地域に適切に分散配置するこ とが望ましい。ここでは，宇部市近郊に一箇所増やしている。これら の結果, リサイクルのうち, 通常のボード類など（表中マテリアルリ サイクル）と高付加価值型材料の割合がオーダー的にはほぼ同程度に なり，移送コスト比もシナリオ RcySep2 に比べると Sep-C 以外は下げ ることができている。高付加価值型材料工場には 2000 年実績の家屋 除却木質材からは約 21600 トンが供給できており，現実的な值になっ ていると思われるので, 安定的なチップ供給を行える可能性は指摘で きる。

\section{6. まとめ}

市町村規模の圈域内の住宅除却由来の廃木材資源が，リサイクルに 関する政策シナリオに従って，道路ネットワークからなる圈域内で資 源循環される材料移送状況をシミュレーションする地域ロジスティク スモデルを構築した。山口県を適用事例とした数值計算から，設定し たシナリオ毎に生じる具体的なリサイクルの姿と問題点をある程度指 摘できた。本モデルは, 最善の政策や政策誘導工場立地の最適解を直 接導くものではないが，地理情報システムなど他の立地用件解析シス テムからいくつかのパターンの配置案が与えられたときには，取るべ き政策と域内でのロジスティクスに基づいたリサイクル率と移送コス トの検証が可能である。

木質材の廃棄物問題については，総合科学技術会議に扔いて「ゴミ ゼロ型・資源循環型技術研究」が重点領域として挙げられ, 重視すべ き事項として「循環型社会変革シナリオ研究」が示されている。建築 物のライフサイクルを通して，（各フェーズが連携した）モノと情報の 円滑な流れを促進する高度な資源循環社会システム（規格・法令・制 度等を含んだ総合的概念）を構築していくことが今求められており， 適正な政策立案に際して，本論で報告した地域リサイクルロジスティ クスモデルが活用されることが期待される。

\section{蝴辞}

本研究は，総合技術開発プロジェクト「循環型社会及び安全な環境 形成のための建築・都市基盤整備技術の開発」の中課題「木質系建築 廃棄物発生抑制技術の開発」(平成 12 年度〜 14 年度) の一環として 実施されたものであり 5), , （財）日本建築センターに設置された「社 会システム分科会 資源循環社会モデルWG（主査：野村希晶)」にお いて検討されたことを記し，関係各位に謝意を表します。

\section{考文献}

1) 日本建築学会地球環境委員会資源利用小委員会：建築における資源循罢のモデル 化，資源利用委員会活動報告都（1999-2000 年度），2001．

2）高口洋人，尾島俊雄: 木造住宅と森林資源の日本型循環モデル笨築に関する研究， 日本建築学会計画系論文集，No.544，pp.85-92，2001.6.

3）下田吉之, 井上晋一, 山岸源, 水野稔：大阪府におけるマテリアルフローの推定 と評価一都市における物質・エネルギー代謝と建築の位置づけ その 1 -, 日本 建筑学会計画系論文集, No.546, pp.83-90, 2001.8.

4) 山口県環境生活部: 平成 13 年度山口県産業廃棄物実態調查報告莗, 2002.

5）野村希晶, 有川智, 武藤正臌, 小林均, 福田展淳, 野城智也 : 木造住宅の分別解 体・再資源化の促進に関する研究 その11 リサイクルロジスティクスモデルの 開発一モデル概要，日本建築学会大会学術講演梗概集 A-1，1099-1100，2003.

6) 有川智, 野村希晶, 武藤正樹, 小林均, 福田展淳, 野城智也 : 木造住宅の分別解 体・再資源化の促進に関する研究 その11リサイクルロジスティクスモデルの 開発一結果概要, 日本建築学会大会学術講演梗概集 A-1，1101-1102，2003. 